\title{
In Response to Management of Hyperglycemia in Inhospital COVID-19 Patients: A Review
}

\author{
Sattik Siddhanta \\ Bengal Physician Journal (2020): 10.5005/jp-journals-10070-7033
}

Respected Sir,

I must appreciate the article titled "Management of Hyperglycemia in Inhospital COVID-19 Patients: A Review" published in the last edition of your esteemed journal. The authors have categorically highlighted the importance of stringent glycemic control in patients of COVID-19 and the ways of achieving the same. As rightly highlighted, insulin remains the drug of choice in the in-hospital management of hyperglycemia and should be commenced as early as possible. However, the advantages and disadvantages of each and every group of antidiabetic medications (both oral and parenteral) have been mentioned in serial points. The algorithm for the maintenance of insulin infusion is validated and must be practiced rigorously in clinical care settings. The real-life COVID patient is highly representative of the swarm of similar cases which we commonly encounter in our clinical practice.

However, there are a few points worth mentioning. Firstly, self-monitoring of blood glucose is an extremely crucial tool to look for glycemic variability not only during inpatient admission but also during discharge as well at home. Hence, all patients should be advised to keep a functional glucometer with adequate glucose strips in hand and accordingly one must titrate the therapeutic regimen if one's clinical situation demands. Secondly, type 2 diabetes mellitus is an inflammatory disease leading to insulin resistance and beta cell dysfunction. Hydroxychloroquine $(400 \mathrm{mg}$ OD) has been approved by Drugs Controller General of India (DCGI) as an adjunct to lifestyle modifications-diet and exercise-and
Department of General Medicine, IPGMER/SSKM Hospital, Kolkata, West Bengal, India

Corresponding Author: Sattik Siddhanta, Department of General Medicine, IPGMER/SSKM Hospital, Kolkata, West Bengal, India, Phone: +91 9433151126, e-mail: drcalmed@gmail.com

How to cite this article: Siddhanta S. In Response to Management of Hyperglycemia in Inhospital COVID-19 Patients: A Review. Bengal Physician Journal 2020;7(3):76.

Source of support: Nil

Conflict of interest: None

two other oral antidiabetic medications to improve glycemic control in type 2 diabetes mellitus, and it shows promising benefit in COVID-19 as well. The novel mechanism of its glucose-lowering action is observed as it offers postreceptor inhibition of insulin degradation, there by significantly reducing the inflammatory load. Numerous studies have confirmed a significant $\mathrm{HbA} 1 \mathrm{c}$ reduction of $0.87-3.3 \%$ points in addition to reducing fasting and postprandial plasma glucose levels. Few recent studies have shown that treatment with hydroxychloroquine in COVID-19 was associated with a significant reduction or disappearance of viral load. This dual benefit in glycemic reduction as well as use as chemoprophylaxis and in treatment of COVID-19 makes it an apt and preferred choice as an add-on medication in patients of COVID-19 infection with uncontrolled diabetes mellitus.

(c) The Author(s). 2020 Open Access This article is distributed under the terms of the Creative Commons Attribution 4.0 International License (https:// creativecommons.org/licenses/by-nc/4.0/), which permits unrestricted use, distribution, and non-commercial reproduction in any medium, provided you give appropriate credit to the original author(s) and the source, provide a link to the Creative Commons license, and indicate if changes were made. The Creative Commons Public Domain Dedication waiver (http://creativecommons.org/publicdomain/zero/1.0/) applies to the data made available in this article, unless otherwise stated. 